\title{
DETERMINATION OF SOLUBLE SALTS IN INTERSTITIAL WATER OF FLUVIAL SEDIMENTS BY IE-HPLC
}

\author{
SYLVIA. V. COPAJA ${ }^{2 *}$ VESNA NÚÑEZ S. ${ }^{1}$ AND DAVID VÉLIZ ${ }^{2,3}$ \\ ${ }^{1}$ Departamento de Química, ${ }^{2}$ Departamento de Ciencias Ecológicas, ${ }^{3}$ Instituto de Ecología y Biodiversidad. Facultad de Ciencias.
}

Universidad de Chile. Casilla 653 Ñuñoa, Santiago, Chile.

(Received: August 28, 2013 - Accepted: February 24, 2014)

\begin{abstract}
An ionic exchange high resolution liquid chromatography (IE-HPLC) method for determination of cations and anions in interstitial water of sediments, affluent and effluent of dams is proposed in this paper.

Cations: $\mathrm{Na}^{+}, \mathrm{Ca}^{2+}, \mathrm{K}^{+}$, and $\mathrm{Mg}^{2+}$ and anions: $\mathrm{Cl}^{-}, \mathrm{CO}_{3}{ }^{2-}, \mathrm{NO}_{3}^{-}$and $\mathrm{SO}_{4}{ }^{2-}$ were analyzing by IE-HPLC method. Optimized analytical conditions were validated in terms of accuracy, recovery and detection limit. The method of flame spray atomic absorption spectrophotometer (AAS) was used as an additional method for the determination of $\mathrm{Ca}$ and $\mathrm{Mg}$. It must be indicated that cations may be analyzed by several analytical methods such as AAS, ICP, etc., but there are not enough methods to analyze anions; IE-HPLC methods are good alternative to determine these ions.

The aim of this study was to determine ions in interstitial water in the affluent and effluent of the Chilean dams Cogotí, Corrales, La Paloma, Rapel and Recoleta in order to determine if the water is suitable for irrigation or human consumption and estimate the effect of dams on water quality. The results indicate that the highest concentrations observed were for the cations: $\mathrm{Ca}^{2+}$ (mean $\left.43.5 \mathrm{mgL}^{-1}\right), \mathrm{Na}^{+}\left(\right.$mean $\left.16.4 \mathrm{mgL}^{-1}\right), \mathrm{Mg}^{2+}\left(\mathrm{mean}^{-12.6} \mathrm{mgL}^{-1}\right)$, and K${ }^{+}\left(\mathrm{mean}^{-1} 3 \mathrm{mgL}^{-1}\right)$. The highest concentration of anions was found for $\mathrm{CO}^{2-}$ (mean $55.9 \mathrm{mgL}^{-1}$ ); the concentrations of $\mathrm{SO}_{4}^{2-}, \mathrm{Cl}^{-}$and $\mathrm{NO}_{3}^{-}$reached $59.3 \mathrm{mgL}^{-1}, 12.8 \mathrm{mgL}^{-1}$ and 27.0 $\mathrm{mgL}^{-1}$, respectively. The results indicate that although the origin of soluble salts is lithogenic, the high concentrations of these salts found in some places indicate anthropogenic effect, either by direct or indirect discharges or by diffuse pollution. These high concentrations may be significant, considering that these waters are used mainly for irrigation, which would affect the quality of agricultural soils irrigated with this moderately saline water.
\end{abstract}

Keywords: Fluvial sediments, IE-HPLC (high-resolution ion exchange liquid chromatography), dams, soluble salts.

\section{INTRODUCTION}

Water is one the major components of environmental resourses ${ }^{1}$. Freshwater systems are currently considered to be among the most threatened ecosystems of the planet ${ }^{2}$; it has been estimated that the reduction in their biological diversity is much greater than in the most affected terrestrial ecosystem ${ }^{3}$. This is especially relevant in the fluvial systems of the semi-arid Mediterranean region of Chile between, $30^{\circ} \mathrm{S}$ and $34^{\circ} \mathrm{S}$, which have a hydrological regime with significant cyclical changes at yearly and inter-annual scales ${ }^{4}$. The long dry periods produce a decrease in river flows, which may even stop in drought years, altering both the availability and the quality of the water. Industrial agriculture and especially mining activities in the area necessarily imply inputs of organic and inorganic ions and compounds, which accumulate in sediments. Thus it is important to know the salt composition of the interstitial water, which is interchanged with the water column depending mainly on the $\mathrm{pH}^{5-7}$. Considering the great importance of the hydrology, the alterations caused by humans, especially due to the construction of dams, would have ecological consequences in these systems ${ }^{2}$.

Dams are usually built to insure water supply for drinking water and for agriculture; construction of hydroelectric dams began later ${ }^{8}$. It has been estimated that there are more than 45,000 dams greater than $15 \mathrm{~m}$ in height in the world ${ }^{9}$. Studies of water quality in watersheds have received increasing attention in the last few decades, since these have been deteriorating due to the increase in human habitation near rivers and to the increasing degree of industrialization $^{10}$.

Contaminated sediments not only affect directly the environmental health of aquatic systems, they may also be of lithogenic origin or produce indirect effects, since they have the capacity to re-suspend contaminants in the water column, making them available for the organisms that live there. Re-suspension liberation mechanisms occur in the sediment/water interphase, in which the main chemical reactions occur that determine the mobility of nutrients and contaminating substances. Considering that there are dams in a number of rivers in Chile and that mineral salts may accumulate in the zone of the dam ${ }^{11,12}$, the objective of this study was to determine the concentrations of the soluble ions in the saturation extract of sediment or interstitial water of the affluent and effluent of five dams: Rapel (VI Región), Cogotí, La Paloma, Recoleta and Corrales (IV Región), using the previously validated method of ionic interchange high resolution liquid chromatography (IE-HPLC) and flame atomization atomic absorption spectrophotometry (AAS) as a complementary method. These methods may be used to establish the input of soluble salts from sediments to the water column, which indicates the quality of the sediments. The concentrations of these salts must be considered if the water is used for human consumption and/or irrigation ${ }^{13}$.

\section{EXPERIMENTAL}

\section{Study zone}

We studied the effluent and affluent of all the large dams present in valleys from $30^{\circ} \mathrm{S}$ to $34^{\circ} \mathrm{S}$ in Chile, which were built at different times and whose water has different uses. Three of these dams are in the Limari River Basin: Recoleta (1934), Cogotí (1938) and La Paloma (1966); these are used exclusively for agricultural irrigation. The Corrales dam is in the Choapa River Basin; it was constructed in 2001 for irrigation of the Choapa valley. Finally, the Rapel dam in the VI Region was built in 1968 for agricultural irrigation and production of electrical energy (Figure 1).

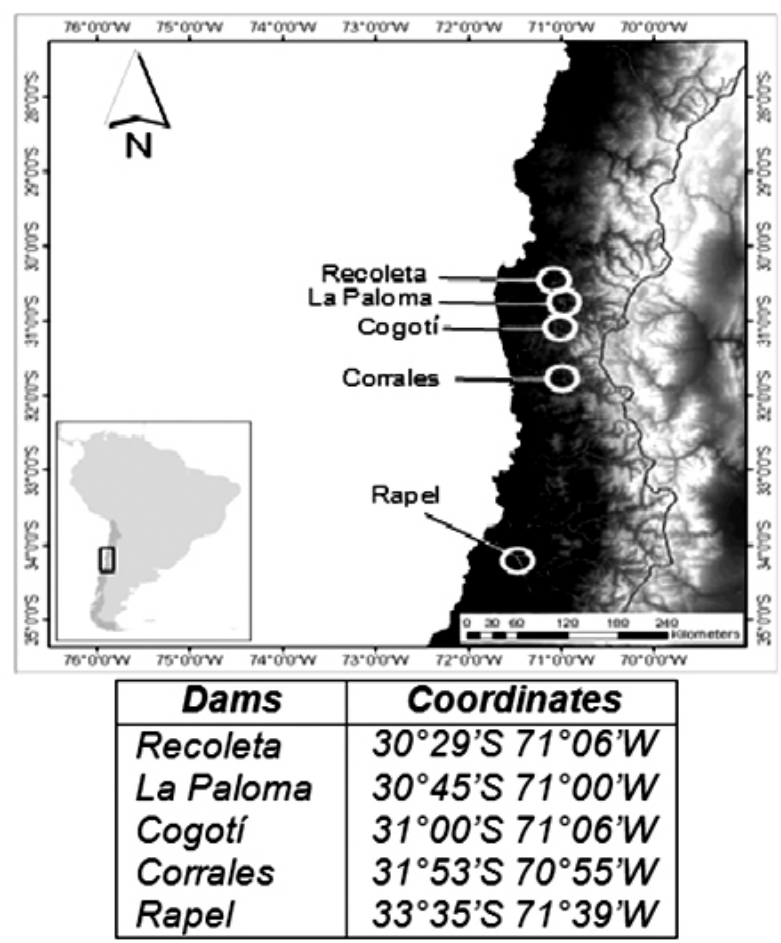

Figure 1: Location of Basins studied in central Chile. 


\section{Sampling}

We sampled these systems in two seasons, high flow (October-November, 2010) and low flow (January-March, 2011). Sediments were sampled in three sites above and three sites below the dams in triplicate $(1 \mathrm{~kg}$ each, collected in polyethylene flasks) according to the protocol for sediments ${ }^{14}$, which requires collecting samples with a plastic shovel from the top 10 centimeters of the superficial sediment zone. Samples were brought to the laboratory and stored at $4{ }^{\circ} \mathrm{C}$; the three samples from each site were mixed and homogenized in order to have sufficient material for analysis.

To obtain interstitial water the sediments were filtered with filter paper. In the laboratory we measured the $\mathrm{pH}$ and $\mathrm{EC}$ of the interstitial water using a portable multiparameter meter (VWR multi 340i).Samples of Interstitial water were filtered using PDVF membranes with $0.45 \mu \mathrm{m}$ pore size and $13 \mathrm{~mm}$ diameter (Millipore MillexTM).

\section{Determination of soluble cations and anions by IE-HPLC}

The determination of soluble salts in interstitial water samples was done by IE-HPLC (Waters 1515) Isocratic HPLC Pump with a conductivity detector (Waters 432), using cationic (IC-Pack Cation MD) and anionic (IC-Pak HJC) columns. The following soluble ions were measured; Cations: $\mathrm{Na}^{+}, \mathrm{K}^{+}, \mathrm{Ca}^{2+}$ and $\mathrm{Mg}^{2+}$; Anions: $\mathrm{SO}_{4}^{2-}, \mathrm{Cl}^{-}, \mathrm{NO}_{3}^{-}$and $\mathrm{CO}_{3}{ }^{2-}$. Isocratic conditions were used with injection volume $50 \mu \mathrm{L}$ and mobile phase flow $1.0 \mathrm{~mL} / \mathrm{min}$. for cations and $1.2 \mathrm{~mL} / \mathrm{min}$. for anions.

The mobile phase for cations was prepared with $0.0296 \mathrm{~g}$ EDTA (Merck $\mathrm{p}$. a.) and $200 \mu \mathrm{L}$ concentrated $\mathrm{HNO}_{3}$ suprapur ${ }^{\circledR}$ Merck, diluted to $1 \mathrm{~L}$ with MilliQ water. The mobile phase for anions was composed of concentrated borate/ gluconate prepared with $34 \mathrm{~g}$ boric acid (Merck p. a.), $23.5 \mathrm{~mL}$ gluconic acid (Merck p. a.), $8.6 \mathrm{~g}$ lithium hydroxide (Merck p. a.) and $250 \mathrm{~mL}$ glycerine (Merck), diluted to $500 \mathrm{~mL}$ with MilliQ deionized water. To $20 \mathrm{~mL}$ of this solution we added $120 \mathrm{~mL}$ acetonitrile (Merck HPLC grade) and diluted to $1 \mathrm{~L}$ with MilliQ deionized water. Analytes identification was determined by retention time $\left(\mathrm{t}_{\mathrm{R}}\right)$ compared with standards (Merck titrisol). Cation and anion concentrations were estimated using calibration curves generated with standards. Data quality was monitored by measuring element concentration in procedural blanks and synthetic preparations of deionized water (MilliQ) with analytes.

\section{Validation of methods for soluble cations and anions}

The validation of methods included the analysis of parameter exactitude, precision, linear range, detection limit and quantification limit.

\section{Ionic Exchange liquid chromatography (IE-HPLC)}

We prepared a set of standard samples using Titrisol Merck standards for the calibration curve. Deionized water MilliQ grade was used for the dilutions. The sensitivity and linear range were obtained from the calibration curve. For the recovery we prepared three solutions of known concentration in the low, medium and high sectors of the curve for later analysis. Recovery, which corresponds to the exactitude of the method, was calculated with the following formula:

$$
\% \text { Recovery }=\frac{\text { Measured Concentration } \times 100}{\text { Real Concentration }}
$$

Precision was evaluated in a sample of known concentration, prepared as above, measured on different days. To determine the limits of detection (LOD) and quantification (LOQ) the following equations were used:

$$
L O Q=\frac{Y_{b l}+10 S_{b l}}{b} \quad L O D=\frac{Y_{b l}+3 S_{b l}}{b}
$$

$b$ : for IE-HPLC is the slope of the concentration curve $v s$. area; for AAS it is the slope of the concentration curve $v s$. absorbance.

$Y_{b l}$ : for IE-HPLC is the intercept of the concentration curve $v s$. area; for AAS it is the absorbance of the blank.

$S_{b l}$ : for IE-HPLC is the intercept of the concentration curve vs. standard deviation; for AAS it is the standard deviation of the absorbance of the blank.
HPLC, except that dilutions were made with $2 \% \mathrm{HNO}_{3}$ suprapur ${ }^{\circledR}$ (Merck).

$\begin{array}{llll}\text { a) } & \text { Calcium } & \text { b) } & \text { Magnesium } \\ \text { - } & \text { Wave length: } 422.43 \mathrm{~nm} & \text { - } & \text { Wave length: } 285.15 \mathrm{~nm} \\ \text { - } & \text { Air-acetylene flame } & \text { - } & \text { Air-acetylene flame } \\ \text { - } & \text { Flow: } 2.0 \mathrm{Lmin}^{-1} & \text { - } & \text { Flow: } 1.8 \mathrm{Lmin}^{-1} \\ \text { - } & \text { Lamp current: } 10 \mathrm{~mA} & \text { - } & \text { Lamp current: } 15 \mathrm{~mA}\end{array}$

\section{Statistical treatment of the data}

To test for differences in $\mathrm{pH}$ and $\mathrm{EC}$ between affluent and effluents we performed a permutation test using the program PERM $1.0^{15}$. This method is ideal for samples of small size; it compares an observed value (e.g., the mean of the differences between observed values) with a randomized distribution of the differences between means. The procedure used 1000 permutations and was repeated 10 times for each analysis in order to estimate the stability of the p-values. If the difference among analyses was greater than $1 \%$ the number of randomizations was increased.

Piper diagrams ${ }^{16}$, were constructed to represent the majority of the anions and cations per study zone. In order to interpret the diagrams in greater detail; ions were represented in meqL $\mathrm{L}^{-1}$ percentages. Each vertex of a triangle represents $100 \%$ of a cation or anion. Finally, integrated rhomboid diagrams were constructed, in which the sum of cations $\left(\mathrm{Ca}^{2+}+\mathrm{Mg}^{2+}\right),\left(\mathrm{K}^{+}+\mathrm{Na}^{+}\right)$and anions $\left(\mathrm{CO}_{3}^{2-}+\mathrm{NO}_{3}^{-}\right)$and $\left(\mathrm{SO}_{4}^{2-}+\mathrm{Cl}^{-}\right)$are represented.

\section{RESULTS AND DISCUSSION}

\section{Validation of analytic methods}

Figures 2 and 3 show the chromatograms obtained for the cations and anions analyzed, respectively (standard solution $30 \mathrm{mgL}^{-1}$ ), and Table 1 indicates the values of the parameters obtained in the validation by IE-HPLC and AAS methods. These values show low LOD; the lowest value was found for $\mathrm{Mg}^{2+}$ and the highest for $\mathrm{K}^{+}$. Both the recovery and the percent of coefficient of variation $(\% \mathrm{CV})$ indicate that the analyses were accurate and exact. The values show that the method validated by IE-HPLC and AAS allowed the determination of the cations of $\mathrm{Na}, \mathrm{K}, \mathrm{Ca}$ and $\mathrm{Mg}$ and the anions $\mathrm{CO}_{3}{ }^{2-}, \mathrm{Cl}^{-}$, $\mathrm{NO}_{3}{ }^{-}$and $\mathrm{SO}_{4}{ }^{2-}$ with acceptable detection limits, good precision and recovery. It is worth noting that although there are other methods with better detection limits for cations such as ICP, AAS, etc., this not true for anions, in which the analytical methods for their determination are scarcer, especially for low concentrations.

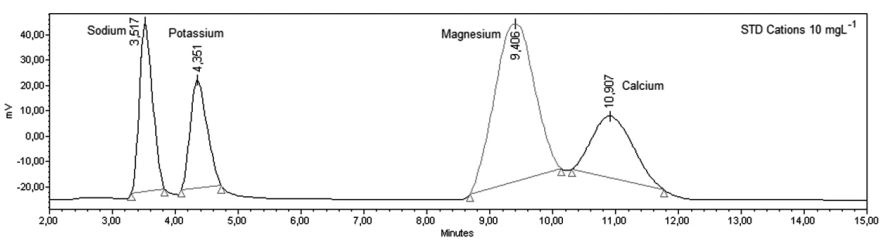

Figure 2: Cation Chromatogram.

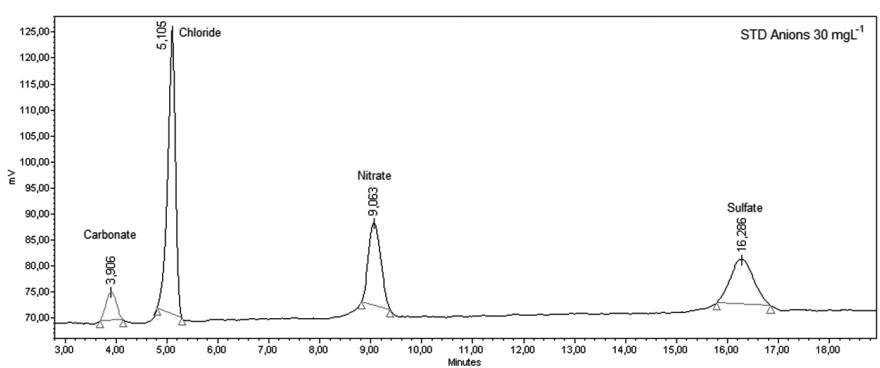

Figure 3: Anion Chromatogram. 
Table 1: Parameters for validation of IE-HPLC and AAS method.

\begin{tabular}{|c|c|c|c|c|c|c|}
\hline Ions & $\begin{array}{c}\text { LOD } \\
\left(\mathbf{m g L}^{-1}\right)\end{array}$ & $\begin{array}{c}\text { LOQ } \\
\left(\mathbf{m g L}^{-1}\right)\end{array}$ & $\begin{array}{c}\text { \% } \\
\text { Recovery }\end{array}$ & \% CV & Calibration curve & $\mathbf{R}^{\mathbf{2}}$ \\
\hline $\mathrm{Na}^{+}$ & 0.9 & 1.9 & 98.7 & 1.7 & $\mathrm{Y}=96820 \mathrm{X}-42305$ & 0.988 \\
\hline $\mathrm{K}^{+}$ & 2.4 & 2.8 & 100.7 & 1.8 & $\mathrm{Y}=95595 \mathrm{X}-219123$ & 0.998 \\
\hline$* \mathrm{Mg}^{2+}$ & 0.02 & 0.02 & 97.7 & 3.5 & $\mathrm{Y}=0.9946 \mathrm{X}+0.0206$ & 0.995 \\
\hline$* \mathrm{Ca}^{2+}$ & 0.2 & 0.2 & 102.1 & 2.5 & $\mathrm{Y}=0.0602 \mathrm{X}+0.0078$ & 0.999 \\
\hline $\mathrm{CO}_{3}{ }^{2-}$ & 1.1 & 1.3 & 101.0 & 0.7 & $\mathrm{Y}=2704 \mathrm{X}-2737.5$ & 0.998 \\
\hline $\mathrm{Cl}^{-}$ & 0.2 & 0.4 & 100.1 & 2.3 & $\mathrm{Y}=69.588 \mathrm{X}+166.67$ & 0.985 \\
\hline $\mathrm{NO}_{3}{ }^{-}$ & 1.4 & 1.7 & 101.8 & 2.4 & $\mathrm{Y}=3969.3 \mathrm{X}+5162.3$ & 0.997 \\
\hline $\mathrm{SO}_{4}{ }^{2-}$ & 1.8 & 1.9 & 102.7 & 0.6 & $\mathrm{Y}=8231.4 \mathrm{X}-14947$ & 0.993 \\
\hline
\end{tabular}

\section{*Cations validated by $A A S$}

Physical and chemical characterization of interstitial water

The parameters measured in the laboratory, $\mathrm{pH}$ and $\mathrm{EC}$, for the samples of interstitial water are shown in table 2 and Figure 4.

$\boldsymbol{p H}$ : Generally the mean $\mathrm{pH}$ of the affluent and effluent of the reservoirs were slightly alkaline; the most acid $\mathrm{pH}$ was found in the affluent of the Cogotí reservoir (high flow sample; $\mathrm{pH} 6.1 \pm 0.3$ ), while the most alkaline was found in the effluent of the Recoleta reservoir (low flow sample; $\mathrm{pH} 8.2 \pm 0.2$ ). No common pattern was found in the changes of $\mathrm{pH}$ from affluent to effluent among the reservoirs. Although in La Paloma and Recoleta the $\mathrm{pH}$ was lower in the low flow sample, the difference was not significant for most comparisons. The $\mathrm{pH}$ did not show significant temporal variation, which has been observed in other systems ${ }^{16}$.
Electrical Conductivity $(\boldsymbol{E C})$ : EC indicates the concentrations of different salts, which were different between dams. The lowest EC was found in the effluent of the Cogotí reservoir during low flow $\left(\mathrm{EC} 0.35 \pm 0.02 \mathrm{mScm}^{-1}\right)$, while the highest value was found in the effluent of the Recoleta reservoir during low flow (EC $1.26 \pm 0.09 \mathrm{mScm}^{-1}$ ). There was no clear pattern to the differences between affluent and effluent. Although there was a tendency to increase of EC in La Paloma, Rapel and Recoleta in the low flow period, the difference was not always statistically significant. Values $>3 \mathrm{mScm}^{-1}$ indicate salinity problems ${ }^{16}$, so the effluent of the Recoleta reservoir should be the only site with a tendency to be moderately saline (classification $\mathrm{C} 3$; range $0.75-1.25 \mathrm{mSm}-1$ ) ${ }^{17}$.

Table 2: Comparison of $\mathrm{pH}$ and $\mathrm{CE}$ determined in the affluent and effluent of each dam with high and low flow. Mean of three sites in affluent and three sites in effluent, with two replicates.

\begin{tabular}{|c|c|c|c|c|c|}
\hline \multicolumn{2}{|c|}{ DAMS } & \multicolumn{2}{c|}{ pH } & \multicolumn{2}{c|}{ CE (mScm $\left.{ }^{-1}\right)$} \\
\cline { 3 - 6 } & High flow & Low flow & High flow & Low flow \\
\hline \multirow{3}{*}{ Rapel } & Affluent & $7.5 \pm 0.1$ & $8.5 \pm 0.4$ & $0.48 \pm 0.02$ & $0.51 \pm 0.03$ \\
\cline { 2 - 6 } & Effluent & $7.7 \pm 0.2$ & $8.9 \pm 0.1$ & $0.43 \pm 0.03$ & $0.51 \pm 0.03$ \\
\hline \multirow{3}{*}{ Cogotí } & Affluent & $7.0 \pm 0.3$ & $7.1 \pm 0.3$ & $0.62 \pm 0.28$ & $0.77 \pm 0.17$ \\
\cline { 2 - 6 } & Effluent & $7.0 \pm 0.1$ & $7.1 \pm 0.2$ & $0.53 \pm 0.22$ & $0.35 \pm 0.02$ \\
\hline \multirow{3}{*}{ La Paloma } & Affluent & $8.0 \pm 0.3$ & $7.0 \pm 0.1$ & $0.22 \pm 0.13$ & $0.69 \pm 0.08$ \\
\cline { 2 - 6 } & Effluent & $7.5 \pm 0.3$ & $7.4 \pm 0.5$ & $0.32 \pm 0.18$ & $0.42 \pm 0.04$ \\
\hline \multirow{3}{*}{ Recoleta } & Affluent & $7.5 \pm 0.5$ & $7.0 \pm 0.1$ & $0.41 \pm 0.18$ & $0.69 \pm 0.05$ \\
\cline { 2 - 6 } & Effluent & $8.2 \pm 0.2$ & $7.3 \pm 0.1$ & $0.45 \pm 0.13$ & $1.26 \pm 0.87$ \\
\hline \multirow{2}{*}{ Corrales } & Affluent & $7.1 \pm 0.2$ & $*$ & $0.43 \pm 0.10$ & $*$ \\
\cline { 2 - 6 } & Effluent & $7.0 \pm 0.2$ & $7.3 \pm 0.1$ & $0.42 \pm 0.07$ & $0.39 \pm 0.09$ \\
\hline
\end{tabular}

*It was not possible to obtain samples in the Corrales reservoir in low flow campaigns

\section{Variation of ions in affluent and effluent of dams}

Figure 5 shows the mean concentrations of affluent and effluent of cations and anions for the five dams in the two sampling periods. In general, $\mathrm{Ca}^{2+}$ was the ion with the highest concentration in affluent and effluent in all the dams and in the two campaigns, with a mean of $43.5 \mathrm{mgL}^{-1}$; the highest concentration was found in effluent of Recoleta in the low flow campaign $\left(103.7 \mathrm{mgL}^{-1}\right)$ and the lowest concentration was found in Cogotí in the effluent with low flow $\left(28.1 \mathrm{mgL}^{-1}\right)$. Na ${ }^{+}$had a mean $16.4 \mathrm{mgL}^{-1}$; the highest concentration was found in the affluent of Corrales low flow $\left(69.5 \mathrm{mgL}^{-1}\right)$ and the lowest concentration was found in the affluent of La Paloma $\left(2.8 \mathrm{mgL}^{-1}\right)$. The mean concentration of $\mathrm{Mg}^{2+}$ was $12.6 \mathrm{mgL}^{-1}$; the highest concentration was found in the affluent of Recoleta low flow $\left(33.3 \mathrm{mgL}^{-1}\right)$ and the lowest concentration was found in the affluent of La Paloma high flow $\left(8.9 \mathrm{mgL}^{-1}\right) . \mathrm{K}^{+}$had a mean of $2.3 \mathrm{mgL}^{-1}$; the concentration of this cation was below detection limit in most of the reservoirs (Corrales, La Paloma and Recoleta in both affluent and effluent in low flow; the highest concentration was found in the effluent of Recoleta high flow (7.3 $\left.\mathrm{mgL}^{-1}\right)$.
The highest anion concentrations found were those of $\mathrm{CO}_{3}{ }^{2-}$ (mean 55.9 $\mathrm{mgL}^{-1}$ ); this is in agreement with the alkaline $\mathrm{pH}$ of the water (Table 2), the highest concentration was found in the affluent of Recoleta low flow (174.7 $\mathrm{mgL}^{-1}$ ) and the lowest concentration was found in the effluent of Rapel high flow $\left(29.7 \mathrm{mgL}^{-1}\right) . \mathrm{SO}_{4}^{2}$ had the second highest anion concentrations, mean $39.3 \mathrm{mgL}^{-1}$; the highest concentration was found in the effluent of Rapel high flow $\left(123.5 \mathrm{mgL}^{-1}\right)$ and the lowest concentration was found in the affluent of Recoleta low flow $(<\mathrm{LD})$. The concentrations found in the Rapel dam stand out, especially in the effluent, indicating the mobility of this anion whose source is principally mining activities. $\mathrm{Cl}^{-}$had a mean of $12.8 \mathrm{mgL}^{-1}$; the highest concentration was found in the effluent of Recoleta high flow $\left(48.6 . \mathrm{mgL}^{-1}\right)$ and the lowest concentration was found in both affluent and effluent of La Paloma low flow $(<\mathrm{LD})$. The mean of $\mathrm{NO}_{3},-$ was $27.0 \mathrm{mgL}^{-1}$; the highest concentration was found in the effluent of Recoleta low flow $\left(161.1 \mathrm{mgL}^{-1}\right)$ and the lowest concentration was found in both affluent and effluent of Recoleta high flow, in the effluent of Cogotí low flow and the effluent of Corrales low flow $(<\mathrm{LD})$ 


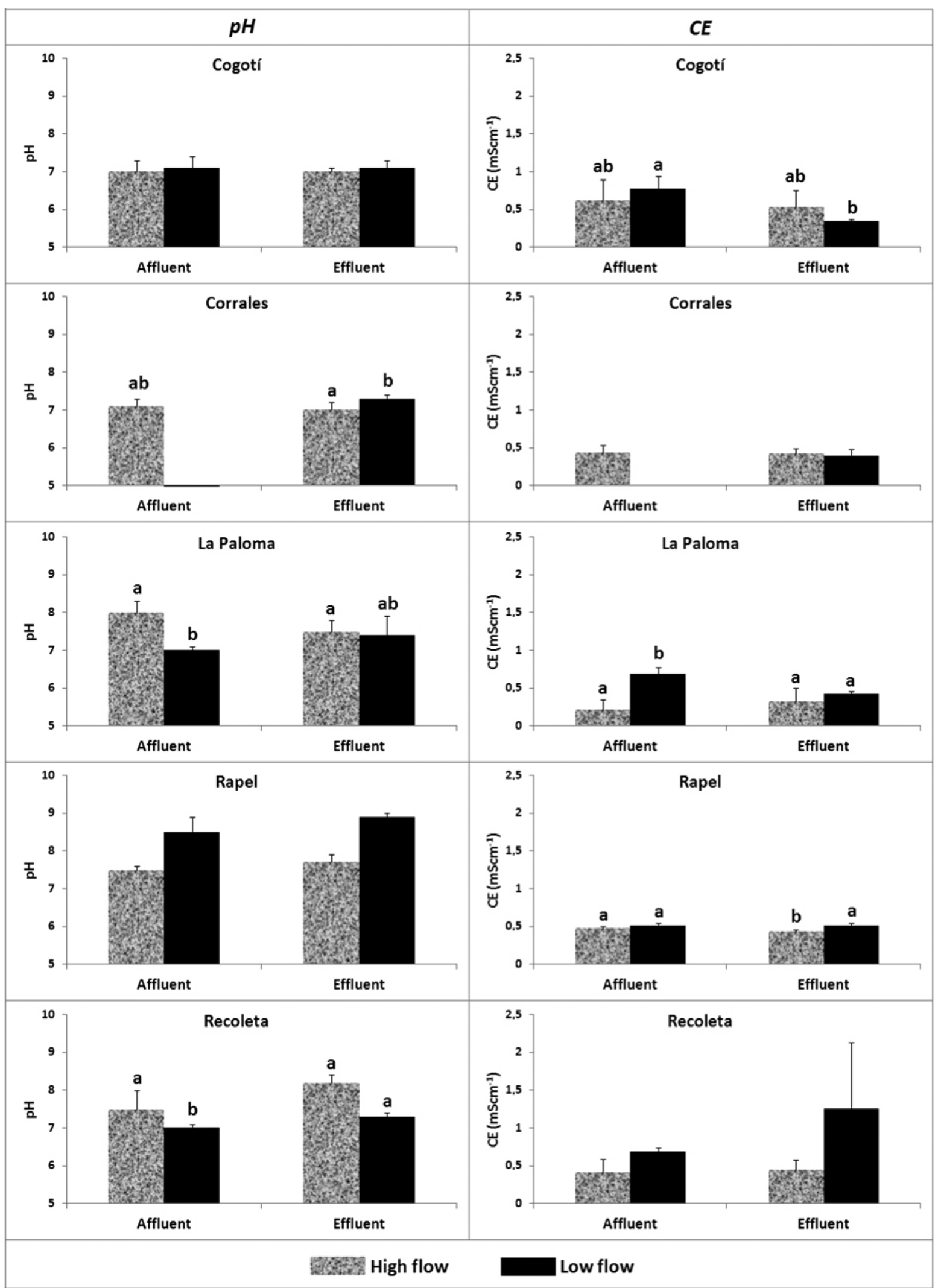

Figure 4: Comparison of $\mathrm{pH}$ and $\mathrm{CE}$ determined in the affluent and effluent of each dam. 

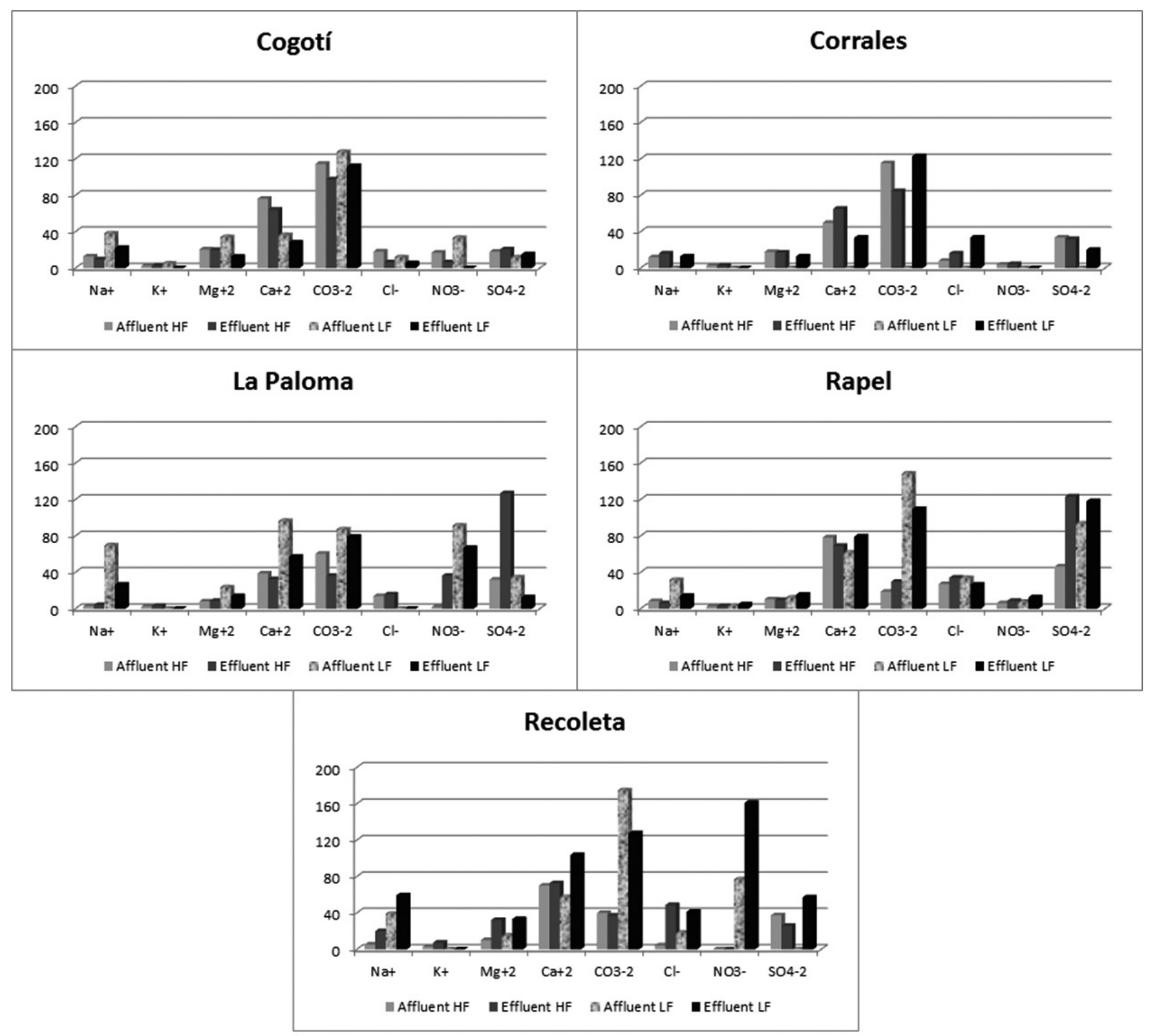

Figure 5: Comparison of cations: $\mathrm{Na}^{+}, \mathrm{K}^{+}, \mathrm{Mg}^{2+}$ and $\mathrm{Ca}^{2+}$ and anions: $\mathrm{CO}_{3}^{2-}, \mathrm{Cl}^{-}, \mathrm{NO}_{3}^{-}, \mathrm{SO}_{4}^{2-}$, for the affluent and effluent of each dam and two campaigns (HF: High Flow; LF: Low Flow; SD corresponding to three sites in affluent and effluent and two replicates). In Corrales Dam samples could not be obtained in the influent due to dryness of the sector in that period.

The concentrations of cations and anions in affluents and effluents of dams were compared with WHO (1996), and all were within the maximum permissible limit. ${ }^{18,19}$. The concentrations also meet the requirements set by regulation NCh 1333 of78 for irrigation water. However, it must considered the dangerous as one can be affected soil irrigated with this water according to the concentration of soluble salts, especially sodium concentration related to calcium and magnesium concentration established by the RAS (adsorbed sodium relation). Figure 6 shows the RAS values in each of the study areas.

In the figure we can see that in most of the reservoirs, except Corrales, the RAS was higher in the low flow season, due to the concentration of salts. RAS values less than 1 indicate water quality S1, while values between 1 and 2 indicate quality S2. It is necessary to consider that in the summer period (low flow) is when more water used for irrigation, so while the water quality is still not dangerous it is necessary to consider possible changes in water quality.

Figure 7 shows the distribution of cations and anions by Piper diagrams. The Piper diagrams indicate a certain similarity among the Cogotí, Corrales and Rapel reservoirs, since there were no major differences in the distribution of cations in the influent and effluent, while in La Paloma and Recoleta differences were observed before and after the dam.

There were two significant downstream increases, for $\mathrm{SO}_{4}^{2-}$ in La paloma and in $\mathrm{Cl}^{-}$for Recoleta. The Rapel dam showed the largest differences between sampling periods, especially $\mathrm{SO}_{4}^{2-}$, whose concentrations depended on the flow. These results indicate that in some sites both cations and anions were present in elevated concentrations, indicating an effect of contamination by these salts.

Piper diagrams as a classification of water are shown in Table 3. 


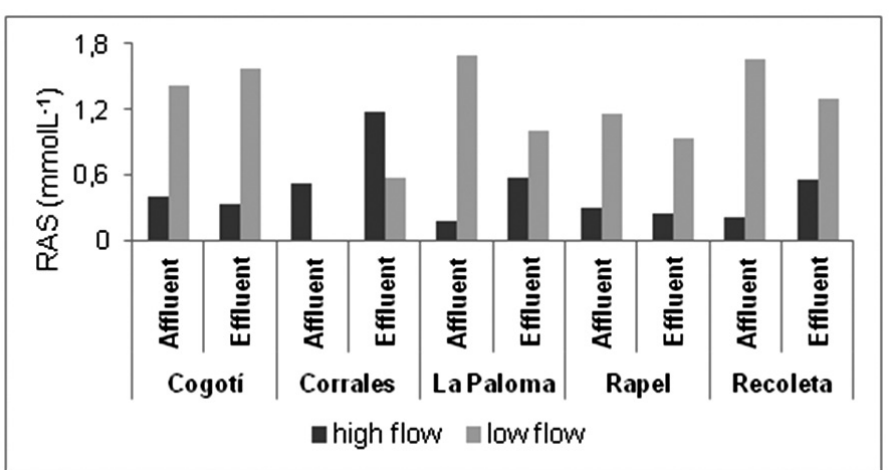

Figure 6: RAS, relation adsorbed sodium:, $R A S=\frac{m m o l ~ N a}{[((C a+M g) m m / 2}$ in different zones of the dams.
Table 3. Classifications of interstitial according Piper diagram.

\begin{tabular}{|l|l|}
\hline Dams & Water classification \\
\hline Cogotí, Corrales & Nitrated water, carbonate and calcium \\
\hline La Paloma & Nitrated water, carbonate, calcium and magnesium \\
\hline Rapel & Chlorinated water, sulfate and calcium \\
\hline Recoleta & $\begin{array}{l}\text { Nitrated water, chloride, carbonate, calcium and } \\
\text { magnesium }\end{array}$ \\
\hline
\end{tabular}

The soluble salts present in the interstitial sediment water may diffuse to surface waters, affecting their quality and that of the subterranean waters, as has been observed in other places ${ }^{21}$.

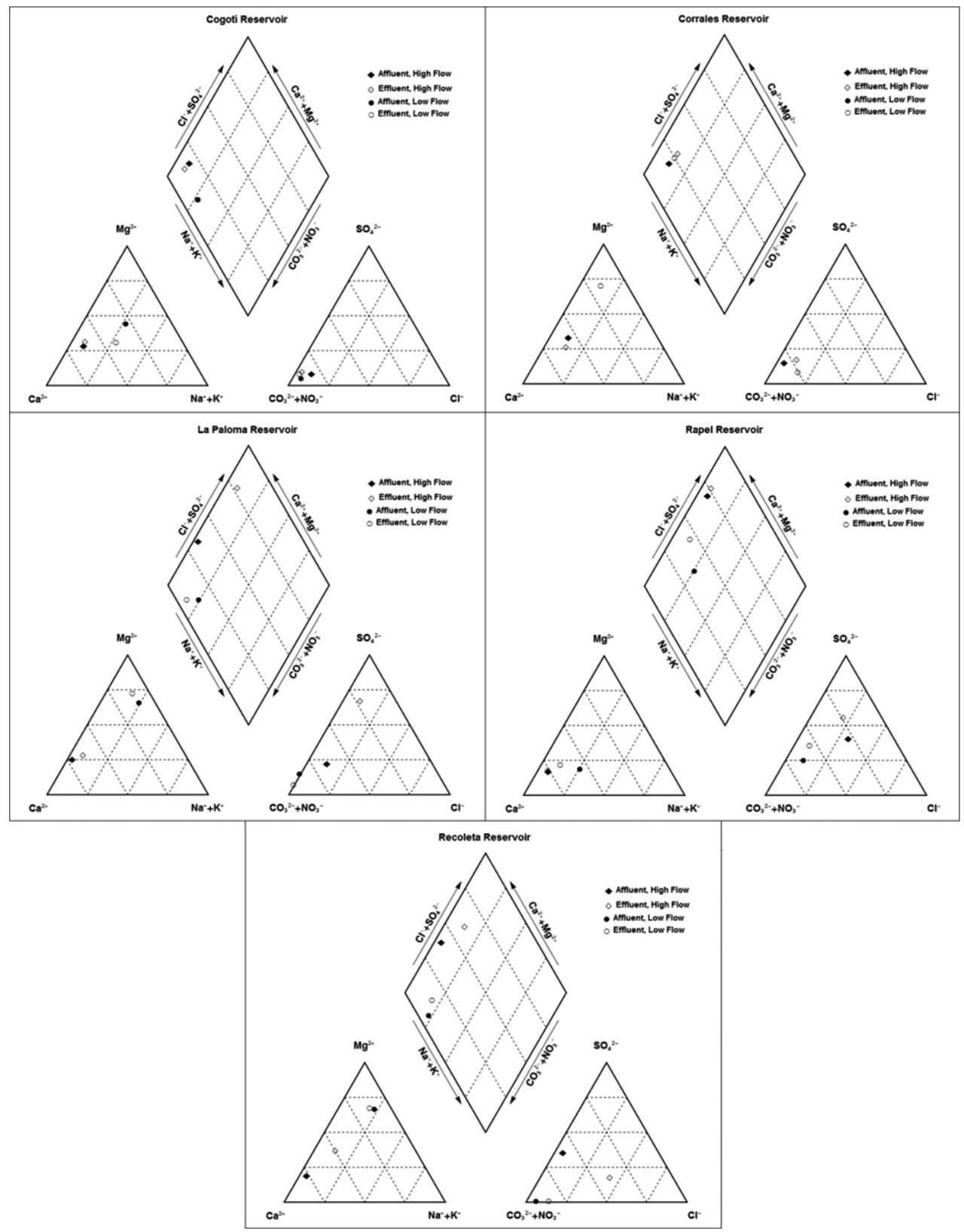

Figure 7: Piper diagrams. 


\section{CONCLUSIONS}

In this study we optimized the IE-HPLC method to analyze cations and anions in interstitial sediment water. Cations may be analyzed by several analytical methods such as AAS, ICP, etc., but there are not enough methods to analyze anion, thus the IE-HPLC method is good alternative to determine these ions

The water classification of the Cogotí, Corrales and La Paloma dams is carbonated, calcium and magnesium, while the waters of the Rape dam are sulfated and calcium carbonated. In the Recoleta dam the calcium concentration of the affluent was greater with high water flow, while in the low flow period magnesium was high in both affluent and effluent. Calcium had the highest concentrations among the anions in both flow conditions, while sulfate, carbonate and chloride were found in the effluent in the period of low flow. This dam has a strong anthropic influence due to the city of Ovalle, which was also reflected in greater alkalinity and high EC values.

In general, the La Paloma, Cogotí and Corrales dams showed a common pattern with slight differences; they had high concentrations of calcium, magnesium and carbonate in both affluent and effluent. Magnesium was important in these three dams especially in the low flow period, probably due to effects of the concentration of these salts. These high concentrations may be significant, considering that the use of these waters is mainly for irrigation, which would affect the quality of agricultural soils irrigated with this moderately saline water. RAS should be considered to define water quality.

\section{ACKNOWLEDGEMENTS}

We thank M. Espinoza, R. Gauci, S. Scott and C. Quezada-Romegialli for their help in the field. The study was financed by Fondecyt projects 1100341, ICM P05-002 and PFB-23.

\section{REFERENCES}

1. S. T. Efe, African Journal of Environmental Studies 2, 6 (2002A)

2. O.E. Sala. F.S. Chapin III. J.J. Armesto, E. Berlow, J. Bloomfield, R. Dirzo, E. Huber-Sanwald, L.F. Huenneke, R.B. Jackson, A. Kinzig, R. Leemans, D.M. Lodge, H.A. Mooney, M. Oesterheld, N.L. Poff, M.T. Sykes, B.H. Walker, M. Walker, D.H. Wall. Science 287, 1770 (2000).

3. H. Niemeyer, P. Cereceda. Hidrografía. Geografía de Chile. Instituto geográfico Militar. Santiago Chile, 320 p. (1984).
4. A. Elosegui, S. Sabater. Conceptos y técnicas en Ecología fluvial. Fundación BBVA. Bilbao. España, 444 p. (2009).

5. R. Wetzel. Limnology. Lake and Rivers Ecosystems. Academic Press. New York, , 106 p. (2001).

6. A. Horne, Ch. Goldman. Limnology. Mc Graw-Hill Co. New York, , 575 p. (1992).

7. P. Morais. Int. J. of Limnol, 44, 105. (2008).

8. C. Nilsson, C.A. Reidy, M. Dynesius, C. Revenga. Science, 308, $405 .($ 2005).

9. T.H. Dang, A. Coynel, D. Orangr, G. Blanc, H. Etcheber, L.A. Le. Sci.Total Environ., 408, 4654 (2010).

10. K. Thorton, B. Kimmel, F. payne. Dam limnology. Ecological perspectives. A Wiley-Interscience Pu. New York, , 246 p. (1990).

11. I. Vila, M. Contreras, V. Montecino, J. Pizarro, D. Adams. Arch.Hydrobiol. Spec. Issues Advanc. Limnol., 55, 31.(2000).

12. Brainwood, M. A., Burgin, S., Maheshwari, B. Agricultural Water Mangement, 70, 151 (2004).

13. A. Simpson, E. Graeme, Batley, A. Chaslton, J. Sharyan. Handbook for Sediment Quality Assessment, (2005).

14. C. Baird, M. Cann. Enviromental Chemistry. New York. W.H. Freeman and Company, 2005, 653 pp.

15 A.M. Piper. Am. Geophys. Union Trans., 25, 914 (1984)

16. T. Mercado F., M. Ortega, E., A. Arenas T., E. Combatt C. Idesia 29, 1 (2011).

17. A. Bermejillo, J. Llera, A. Valdés, D. Cónsoli, M. Venier, C. Salcedo, S. Trollo. Rev. Fac. Cienc. Agrar. 44, 1 (2012).

18. WHO International standard for drinking wáter $3^{\text {rd }}$ edition, Geneva, $p 70$ (1996).

19. G. Vanitha, M. Shunmugavelu International Journal of Environmental Science 2, 2184 (2012)

20. J.A. Ramos-Leal, J. Durazo, T. González-Morán, F. Juárez-Sánchez, A. Cortés-Silva, Y. Karen, H. Johannesson. Rev. Mex. Ciencias Geológicas, 24, 293. (2007).

21. G. Klaver, B. van Os, P. Negret, E. Petelet-Girarud. Science Direct, 148, 718 (2007)

22. Wenfang Zeng, Yongxing Chen, Hairong Cui, Feiyan Wu, Yan Zhy, James, S. Fritz, Journal of Chromatography A., 68, 1118 (2006).

23. L. González, M. Mardones, A. Silva, E. Campos, Rev. Geol. Chile, 26, 145 (1999). 